\title{
Congenital adrenal hyperplasia- presenting as central precocious puberty
}

\author{
Vimal Mavila Veetil', MC Naseerali \\ From 7th APPES Biennial Scientific Meeting \\ Nusa Dua, Bali. 14-17 November 2012
}

\section{Aims}

To demonstrate the presentation of Congenital adrenal hyperplasia $(\mathrm{CAH})$ as central precocious puberty.

\section{Materials and methods}

4 children with mean age of $6.5(5.5,6.5,6.5,7.5)$ who presented to the out patient department with precocious puberty between December 2008 to December 2011were studied.

\section{Results}

3 were boys, out of which 2 were twins. 3 boys were diagnosed to have $\mathrm{CAH}$ after presentation to the OPD. They had mean bone age of 12 years. They had elevated testosterone (mean : $2.4 \mathrm{ng} / \mathrm{ml}$ ) and 17 hydoxyprogesterone ( mean : $24 \mathrm{ng} / \mathrm{ml}$ ) at presentation. They had clinical (testicular volume $5 \mathrm{ml}$ ) and biochemical (mean basal $\mathrm{LH}: 6 \mathrm{ng} / \mathrm{ml}$ )evidence of central precocious puberty. The girl was already diagnosed to have $\mathrm{CAH}$ at birth itself, but was on irregular treatment. She presented with menarche at the age of 7.5 and had basal LH of $8 \mathrm{ng} / \mathrm{ml}$. All the patients were started on replacement with hydrocortisone, fludrocortisones and $\mathrm{GnRH}$ analogue ( Leuprolide depot ).

\section{Conclusions}

Central precocity may be due to undiagnosed CAH. Improperly treated $\mathrm{CAH}$ may also lead to central precocious puberty. Treatment may involve GnRH analogues along with adrenal steroids.

Published: 3 October 2013

MIMS, India
doi:10.1186/1687-9856-2013-S1-P118

Cite this article as: Veetil and Naseerali: Congenital adrenal hyperplasiapresenting as central precocious puberty. International Journal of Pediatric Endocrinology 2013 2013(Suppl 1):P118.
Submit your next manuscript to BioMed Central and take full advantage of:

- Convenient online submission

- Thorough peer review

- No space constraints or color figure charges

- Immediate publication on acceptance

- Inclusion in PubMed, CAS, Scopus and Google Scholar

- Research which is freely available for redistribution 